\title{
Comparative efficacies of intratympanic steroid administration and classic therapy in the management of idiopathic sudden sensorineural hearing loss
}

\author{
İdiopatik ani işitme kaybında intratimpanik steroid uygulaması ile \\ klasik tedavi etkinliğinin karşılaştırılması \\ Murat Gümüşsoy, illker Burak Arslan, İbrahim Çukurova \\ Department of Otorbinolaryngology, Tepecik Training and Research Hospital, İzmir, Turkey
}

\begin{abstract}
Objective: Sudden hearing loss is a sensorineural hearing loss with an unknown etiology at $\geq 30 \mathrm{~dB}$ which appears in 3 days or within a shorter period of time and obstructs three successive frequencies. Our objective in this study is to assess the effectiveness of the combination of classic therapy and intratympanic steroid treatment in the management of idiopathic sudden sensorineural hearing loss.

Methods: One hundred and forty patients diagnosed with idiopathic sudden sensorineural hearing loss in our clinics between February 2010 and June 2012 were separated into 2 groups. Seventy-six patients [37 women $(48.68 \%)$ and 39 men $(51.32 \%)]$ with a mean age of $45.1 \pm 14.16$ years managed with a combination of classic sudden hearing loss and intratympanic steroid treatment (Group 1) and 64 patients [34 women $(53.18 \%)$ and 30 men $(46.82 \%)$ ] with a mean age of $47.6 \pm 17.74$ years managed with only classic sudden hearing loss treatment (Group 2) were included in the study. One month after the study, pure-tone averages and speech discrimination scores of the patients were compared with those obtained 1 month before the treatment.

Results: Pure-tone average of the intratympanic-steroid treatment group was found to be $68.28 \mathrm{~dB}$ before the treatment where in the other group it was $67.21 \mathrm{~dB}$ without any statistically significant difference between groups. When followed-up 1 month after the therapy, pure-tone average was found to be $33.52 \mathrm{~dB}$ in the intratympanic steroid treatment group and $44.46 \mathrm{~dB}$ in the classic therapy group with a statistically significant intergroup difference. Gain was up to $34.76 \mathrm{~dB}$ in the intratympanic steroid treatment group whereas in the classic therapy group, the difference was $22.75 \mathrm{~dB}$ which was found to be statistically significant $(\mathrm{p}<0.05)$.

Conclusion: When treating idiopathic sudden hearing loss, intratympanic steroid treatment which was combined with sudden hearing loss treatment protocol tends to yield significant hearing gain when compared with the classic combined treatment.
\end{abstract}

Key words: Sudden hearing loss, sensorineural hearing loss, intratympanic steroid.

\begin{abstract}
Özet
Amaç: Ani işitme kaybı, nedeni bilinmeyen, üç gün içerisinde veya daha kısa zamanda aniden ortaya çıkan, birbirini takip eden üç frekansı tutan, $30 \mathrm{~dB}$ ve üzerindeki sinirsel tipte işitme kaybıdır. Bu çalışmadaki amacımı, intratimpanik steroid tedavisi ile birlikte klasik tedavi birlikteliğinin idiopatik ani işitme kaybı tedavisinde etkinliğini değerlendirmektir.

Yöntem: Şubat 2010 - Haziran 2012 tarihleri arasında kliniğimizde idiopatik ani işitme kaybı tanısı alan 140 hasta çalışmaya alınarak iki gruba ayrıldı. İntratimpanik steroid tedavisi ve klasik ani işitme kaybı tedavisi alan 76 hasta [37'si kadın (\%48.68), 39'u erkek (\%51.32); yaş ortalaması $45.1 \pm 14.16]$ ile sadece klasik tedavi kombinasyonu uygulanan 64 hasta [34'ü kadın (\%53.18), 30'u erkek (\%46.82); yaş ortalaması 47.6 \pm 17.74$]$ çalışmaya dahil edildi. Tedaviden 1 ay sonra hastaların saf ses ortalamaları ve konuşmayı ayırt etme skoru, tedavi öncesindeki saf ses ortalamaları ve konuşmayı ayırt etme skoru ile karşılaştırıldi.

Bulgular: Tedavi öncesi saf ses ortalaması, intratimpanik steroid tedavi grubunda $68.28 \mathrm{~dB}$, diğer grupta $67.21 \mathrm{~dB}$ olarak bulundu ve istatistiksel olarak aralarında fark yoktu. Tedavi sonrasında 1. ay kontrolünde saf ses ortalaması, intratimpanik steroid tedavi grubunda $33.52 \mathrm{~dB}$, klasik tedavi grubunda $44.46 \mathrm{~dB}$ olarak bulundu ve istatistiksel olarak aralarındaki fark anlamlıdı. İntratimpanik steroid tedavi grubunda kazanç 34.76 dB'e yükselirken, klasik tedavi grubunda fark $22.75 \mathrm{~dB}$ olarak ölçüldü ve bu sonuç istatistiksel olarak anlamlı bulundu $(\mathrm{p}<0.05)$.

Sonuç: İdiopatik ani işitme kaybı tedavisinde, klasik ani işitme kaybı tedavi protokolü ile kombine edilen intratimpanik steriod uygulaması, işitme kazancı yönünden sadece klasik kombine tedavi alan hastalara kıyasla anlamlı sonuçlar vermektedir.
\end{abstract}

Anahtar sözcükler: Ani işitme kaybı, sensorinöral işitme kaybı, intratimpanik steroid.
Correspondence: Murat Gümüşsoy, MD. Tepecik Eğitim ve Araştırma Hastanesi, Kulak Burun Boğaz Hastalıkları Kliniği, Gaziler Caddesi, No: 468, Yenişehir, İzmir, Turkey. e-mail: mgumussoy@hotmail.com

Received: March 4, 2013; Accepted: March 18, 2013; Published online: November 1, 2013
Online available at: www.jmedupdates.org doi:10.2399/jmu.2013002002 QR code: 
Sudden hearing loss is conventionally defined as a sensorineural hearing loss with an abrupt onset at $\geq 30 \mathrm{~dB}$ within $\leq 3$ days and obstructs 3 successive frequencies. Sometimes vertigo or tinnitus may accompany its clinical picture. The etiology of sudden hearing loss (SHL) has not been defined clearly and also different factors are held responsible for its occurrence. Frequently viral, vascular and autoimmune pathologies play a role in the etiology of idiopathic hearing loss. In only $10 \%$ of the cases a single etiologic factor can be detected. ${ }^{[1-3]}$ Various treatment strategies have been tried because of different etiologies of SHL. Histamine, papaverine, atropin, blockage of stellate ganglion, dextrane, betahistine and hyperbaric oxygen treatment can be enumerated among them. Heparin and coumadin have been used for anticoagulation. As supportive treatments bed rest, sedatives, tranquilisants, vitamins, especially vitamin B have been recommended. In SHL, only steroids have established their effectiveness. Spontaneous resolution of SHL has been demonstrated in $32-65 \%$ of the cases in various studies, whereas improvement has been reportedly achieved in higher (48-89\%) percentage of patients under steroidal therapy. ${ }^{[3-6]}$

Among many different approaches and investigations for the treatment of SHL, in intratympanic steroidal therapy, steroids are directly injected into the middle ear. From middle ear through round window, drug passes into inner ear which leads to fewer side effects and higher perilymphatic steroid levels relative to its systemic levels. Intratympanic steroid therapy has gained popularity in recent years in the medical treatment of cochlear diseases. Transtympanic drug application into the inner ear has become prevalent in 1935 with Barany's lidocain application into the middle ear, then in 1950s Shuknecht, later Sakata injected steroids into the inner ear. ${ }^{[7-9]}$ Nowadays successful outcomes have been reported with intratympanic steroid (ITS) applications.

In the present study, the outcomes of management of SHL with combined classic treatment - ITS therapy, versus classic combination treatment protocol were compared as for hearing gain.

\section{Materials and Methods}

This study included a total of 140 patients with the diagnosis of SHL who had applied to our clinics between February 2010 and June 2012 within at most 10 days after the onset of the disease. The patients were divided into 2 groups. Group 1 (ITS + classic SHL treatment) included 76 patients [37 (48.68\%) women, $39(51.32 \%)$ men] with a mean age of
$45.1 \pm 14.16$ years and Group 2 (classic SHL treatment protocol group) included 64 patients [34 (53.18\%) women and $30(46.82 \%)$ men] with a mean age of $47.6 \pm 17.74$ years.

Inclusion criteria were the presence of sensorineural type hearing loss occurring suddenly or within a short time without any identified etiology, hearing loss at $\geq 30 \mathrm{~dB}$ obstructing three successive frequencies in odiologic evaluation, absence of any otologic disease in the affected ear and any past history of SHL treatment.

To determine pre-treatment hearing acuity of the eligible patients complying with the above-mentioned criteria, complete audiologic examinations were performed. Using a Mercury brand silent chamber audiometry device with M142, 125-12000 frequency range, pure-tone threshold averages, speech reception threshold, speech discrimination score (SDS), tympanograms, acoustic reflex measurements were performed at 250, 500, 1000, 2000 and 4000 frequencies. Before the procedure the state of hearing acuity was assessed with full audiologic examination. In the classic treatment group $1 \mathrm{mg} / \mathrm{kg}$ oral methylprednisolone (tapering one quarter of a dose on every 4 days), benzodiazepin (Diazepam $5 \mathrm{mg}$, tid, po), antiaggregants (Pirasetam $4 \times 3 \mathrm{~g}, \mathrm{IV}$ ) and antacids ( $4 \times 2$ tablets) were used. In the ITS+classic treatment group, the patients were laid in supine position with their head turned 30-40 degrees to the unaffected side and under local anesthesia $0.3-0.5 \mathrm{ml}$ dexamethasone $(4 \mathrm{mg} / \mathrm{ml})$ was injected using a dental injector inserted through the junction of posteroinferior-posterosuperior quadrants. The patient was left nearly 30 minutes in this position to ensure complete irrigation of the round window. The patient was asked not to swallow anything during the procedure and for the prevention of vestibular organ irritation during the injection injector and its contents were warmed up to a maintenance temperature. The procedure was applied once daily for 5 days. The results were evaluated in consideration of alterations in pure-tone audiograms (PTAs) at 500, 1000 and $2000 \mathrm{~Hz}$ frequencies and SDS. Gains in PTA over $10 \mathrm{~dB}$ were recorded as a significant improvement. Evaluations were made before the treatment and at postoperative first months and the results were compared. For both groups, pre-treatment PTAs and SDSs and comparative increase rates in their values estimated at postoperative first months were statistically evaluated using $\chi^{2}$; and t-tests

\section{Results}

Classic combination treatment group included 64 patients [34 (53.18\%) women and $30(46.82 \%)$ men] with a mean age of $47.6 \pm 17.74$ years. Intratympanic steroid treatment 
group comprised of 76 patients [37 (48.68\%) women, 39 $(51.32 \%)$ men] with a mean age of $45.1 \pm 14.16$ years.

Pre-treatment PTA was $68.28 \mathrm{~dB}$ in the ITS and 67.21 $\mathrm{dB}$ in the other group without any statistically significant difference between groups $(\mathrm{p}>0.005)$. At post-treatment first month control visits, PTA was found to be $33.52 \mathrm{~dB}$ in the ITS and $44.46 \mathrm{~dB}$ in Group 2 with a statistically significant difference between groups. Hearing gain was increased to $34.76 \mathrm{~dB}$ in the ITS group and it was $22.75 \mathrm{~dB}$ in the control group, with a statistically significant intergroup difference (Table 1). Besides, pre-treatment median speech discrimination scores of the patients were $72.89 \mathrm{~dB}$ and 71.64 $\mathrm{dB}$ in the ITS and Group 2, while the corresponding posttreatment SDSs were $86.44 \mathrm{~dB}$ and $79.58 \mathrm{~dB}$, respectively with a statistically significant difference between groups $(\mathrm{p}<0.005)$.

\section{Discussion}

Sudden hearing loss is a sensorineural hearing loss with an unknown etiology and abrupt onset emerging within $\leq 3$ days at $\geq 30 \mathrm{~dB}$ which obstructs 3 successive frequencies. In only $10 \%$ of the cases with SHL any causative factor can be detected. Targeted treatment can be instituted, when an etiological factor can be identified. However one must not forget that spontaneous resolution can occur in $32-65 \%$ of the cases. Most frequently SHL can be cured within the first two weeks. Hearing loss occurring at low or intermediate frequencies improves better than sudden hearing loss involving higher frequencies or horizontal semicircular canal function. ${ }^{[1-4]}$ Cases with decreased speech discrimination scores, children or elders with sudden hearing loss have a poor prognosis. Up to now, many different drugs or drug combinations have been used in the treatment of the sudden hearing loss. Among them histamine, nicotinic acid, carbogens, diatriozoate meglamine, Dextran, Rheomacrodex, heparin, coumadin, Urografin, furosemide, papaverine and piracetame etc. can be enumerated. Clinical applications have demonstrated that mono-, or combination therapy with steroids is the single established therapy with confirmed efficacy. Partial or complete cure rates during systemic steroid use vary between $49-89 \%$ when compared with untreated cases. ${ }^{[3-6]}$ Some authors have thought to obtain more improved outcomes in the management of SHL with steroid combination therapies and to that end they have formulated some treatment protocols. Vasodilators, volume expanders, vitamins and contrast agents have been used in combination with steroids..$^{[1-12]}$ Despite successful outcomes of some treatment protocols, some authors suggest that generally these combinations are not more effective than steroid monotherapies. ${ }^{[13]}$ Currently practiced and accepted SHL treatment is preferably oral steroid administration. Nearly all clinicians agree that within nearly one month, steroids will be able to provide maximal benefit and maintenance of therapies beyond this period will be ineffective. Response rates to systemic steroids range between 49 and 89 percent. ${ }^{[1,15]}$ Emergence of SHL is presumably attributed to inflammatory processes in the inner ear due to various etiologies as viral infection and ischemia and steroids have been used with their conceivably effectiveness in breaking or reversing this inflammatory cascade. However as is known, systemic steroid administration cannot overcome blood-brain barrier efficiently and thus its adequate levels in CSF and bone tissue cannot be sustained. Indeed, steroids must penetrate into inner ear fluids in order to be effective. To increase steroid concentration in the inner ear fluids, administration of higher systemic doses of steroids can be attempted. However it is apparent that higher doses increase risks of systemic complications. In various studies performed within the last 10 years opinions suggest that additional average hearing gain of $25-50 \%$ has been provided by ITS treatment in patients who had not been adequately benefited from systemic steroid therapy. In ITS

Table 1. Intratympanic steroid administration and classic therapy pure tone audiogram results in the pre- and post-treatment periods.

\begin{tabular}{|c|c|c|c|c|}
\hline Frequency $(\mathrm{Hz}$ & \multicolumn{2}{|c|}{ Classic treatment } & \multicolumn{2}{|c|}{ ITS+classic therapy } \\
\hline $250 \mathrm{~Hz}$ & 67.45 & 44.25 & 69.81 & 34.54 \\
\hline $1000 \mathrm{~Hz}$ & 69.42 & 44.36 & 67.80 & 32.11 \\
\hline $2000 \mathrm{~Hz}$ & 62.56 & 44.52 & 66.42 & 34.17 \\
\hline $4000 \mathrm{~Hz}$ & 68.29 & 42.32 & 69.26 & 32.13 \\
\hline
\end{tabular}

ITS: Intratympanic steroid, PTA: Pure-tone audiogram 
treatment, since the drug is locally applied into the middle ear, its concentration in the middle ear increases and only minimal amounts of the drug pass into systemic circulation. Diverse opinions and modes of practices have been proposed for the types, doses and routes of administration of steroids to be applied on the middle ear. For instance myringotomy, ventilation tube, catheter or needle injection have been used for the application of steroids into the middle ear ${ }^{[16-18]}$ As steroidal formulations and doses, $125 \mathrm{mg} / 2$ $\mathrm{ml}$ methylprednisolone or $1 \mathrm{mg} / \mathrm{ml}$ or $4 \mathrm{mg} / \mathrm{ml}$ dexamethasone have been used. ${ }^{[16,17]}$ In our study, ITS was injected into the middle ear using a dental injector and a dose of 0.2-0.4 $\mathrm{ml}$ dexamethasone $(4 \mathrm{mg} / \mathrm{ml})$. Main advantage of this approach is its easier application with relatively lesser morbidities. None of our patients developed complications during or after the procedure.

In an animal study, dexamethasone was administered through venous route and also as an intratympanic application. ${ }^{[19]}$ After the procedures, drug concentrations in perilymphatic fluid were compared and higher dexamethasone concentrations were demonstrated with intratympanic application of dexamethasone. In that study, histamine administered with intratympanic dexamethasone application favored achievement of higher perilymphatic steroid concentrations. ${ }^{[14]}$ In various studies, these higher perilymphatic concentrations have been demonstrated. ${ }^{[2,21]}$ In a separate study, in cases with failed systemic steroid therapy, through an implanted ventilation tube a total of 4 cycles of ITS therapy were instituted within 10-14 days using $0.4 \mathrm{cc}$ steroid injections $(25 \mathrm{mg} / \mathrm{ml}$ dexamethasone or $125 \mathrm{mg} / 2$ $\mathrm{ml}$ methylprednisolone). In $23 \mathrm{SHL}$ patients, ITS therapy was started 72 weeks after the onset of symptoms. In PTA $44 \%$ resolution of symptoms was detected after intratympanic steroid therapy. On PTA an average hearing gain of $15.2 \mathrm{~dB}$ could be demonstrated. In $8(35 \%)$ of 23 patients improvements in hearing threshold and SBS were observed (average improvements, $48 \%$ and $21 \%$, respectively). ${ }^{[17]}$ In a study by Kopke et al., steroids were applied into the round window through an implanted microcatheter. ${ }^{[18]}$ A total of 9 patients were included in the study. As detected on PTAs, median hearing gain of $50.7 \mathrm{~dB}$ (from $93.2 \mathrm{~dB}$ to $42.5 \mathrm{~dB}$ ) was achieved. In a study performed by Herr et al. in 17 patients with refractory sudden hearing loss, an average improvement rate of $53 \%$ has been reported. ${ }^{[22]}$ Gianoli and $\mathrm{Li}$ applied intratympanic steroid injections in 23 patients refractory to oral steroids and in 10 (44\%) cases they had achieved an additional hearing gain of $15 \mathrm{~dB}$ as detected on PTAs. ${ }^{[17]}$ In our study, at first postoperative control visits, pure-tone audiograms detected higher improvements in the median hearing acuities in the ITS group $(33.52 \mathrm{~dB}$ vs 44.46 $\mathrm{dB}$ in Group 2) with a statistically significant intergroup difference. In the ITS group, hearing gain increased to 34.76 $\mathrm{dB}$, while in the control group it was measured as $22.75 \mathrm{~dB}$ with a statistically significant difference in favour of ITS. Besides pre-treatment median SDS values in the ITS and classic treatment groups were found to be $72.89 \mathrm{~dB}$ and $71.64 \mathrm{~dB}$ and the corresponding post-treatment values were assessed as $86.44 \mathrm{~dB}$ and $79.58 \mathrm{~dB}$, respectively with statistically significant improvement in the ITS group.

\section{Conclusion}

After our review of the studies and available investigations relevant to ITS applications, various advantages of ITS injection therapy can be listed. Amount of steroids entering into systemic circulation after ITS applications can be relatively neglected. Besides, suppression of adrenal cortex after withdrawal of the oral steroids is not encountered in ITS procedures without any need for preventive measures. It can be also used in cases with potential contraindications where intratympanic steroid applications achieve higher drug concentrations in the target organ (perilymphatic fluid) relative to oral administration. It is a minimally invasive and harmless surgical intervention which can be very easily applied under local anesthesia in Meniere's disease. In addition it has an increased cost-effective ratio and can be used in cases with recurrent symptoms. With its above-mentioned advantages, ITS can be easily applied as a combination therapy in the management of ITS. We think that with its improved PTA and SDS outcomes, it will take its place among available classic combination therapies.

Conflict of Interest: No conflicts declared.

\section{References}

1. Shikowitz MJ. Sudden sensorineural hearing loss. Med Clin North Am 1991;75:1239-50.

2. Byl FJ. Sudden hearing loss: eight years' experience and suggested prognostic table. Laryngoscope 1984;94:647-61.

3. Haberkamp TJ, Tanyeri HM. Management of idiopathic sudden sensorineural hearing loss. Am J Otol 1999;20:587-95.

4. Moskowitz D, Lee KJ, Smith HW. Steroid use in idiopathic sudden sensorineural hearing loss. Laryngoscope 1984;94:664-6.

5. Mattox DE, Simmons FB. Natural history of sudden sensorineural hearing loss. Ann Otol Rhinol Laryngol 1986:463-80.

6. Rauch SD. Intratympanic steroids for sensorineural hearing loss. Otolaryngol Clin North Am 2004;37:1061-74.

7. Barany R. Die Beinflussung des Ohrensausens durch intravenöse Lokalanaestetica. Acta Otolaryngol 1935;23:201-3.

8. Schuknecht HF. Ablation therapy in the management of Meniere's disease. Acta Otolaryngol 1957;132:1-42. 
9. Sakata E, Itoh A, Ohtsu K, et al. Pathology and treatment of cochlear tinnitus by blocking with \%4 lidocaine and Decadron infusion. Practica Otologica (Kyoto) 1982;75:2525-35.

10. Zadeh MH, Storper IS, Spitzer JB. Diagnosis and treatment of sudden-onset sensorineural hearing loss: a study of 51 patients. Otolaryngol Head Neck Surg 2003;128:92-8.

11. Leong AC, Fairley JW, Padgham ND. Sudden hearing loss. Clin Otolaryngol 2007;32:391-4.

12. Conlin AE, Parnes LS. Treatment of sudden sensorineural hearing loss: I. A systematic review. Arch Otolaryngol Head Neck Surg 2007;133:573-81.

13. Wilkins SA Jr, Mattox DE, Lyles A. Evaluation of a shotgun regiment for sudden hearing loss. Otolaryngol Head Neck Surg 1987;5:74-80.

14. Chandrasekhar SS. Intratympanic dexamethasone for sudden sensorineural hearing loss: clinical and laboratory evaluation. Otol Neurotol 2001;22:18-23.

15. Alexiou C, Arnold W, Fauser C, et al. Sudden sensorineural hearing loss:Does application of glucocorticoids make sense? Arch Otolaryngol Head Neck Surg 2001;127:253-8.
16. Ho HG, Lin HC, Shu MT, Yang CC, Tsai HT. Effectiveness of intratympanic dexamethasone injection in sudden-deafness patients as salvage treatment. Laryngoscope 2004;114:1184-9.

17. Gianoli GJ, Li JC. Transtympanic steroids for treatment of sudden hearing loss. Otolaryngol Head Neck Surg 2001;125:142-6.

18. Kopke RD, Hoffer ME, Wester D, O’Leary MJ, Jackson RL. Targeted topical steroid therapy in sudden sensorineural hearing loss. Otol Neurotol 2001; 22:475-9.

19. Itoh A, Sakata E. Treatment of vestibular disorders. Acta Otolarygol 1991;481:617-23.

20. Nomura Y. Otological significance of the round window. Adv Otorhinolaryngol 1984;33:1-162.

21. Parnes LS, Sun AH, Freeman DJ. Corticosteroids pharmacokinetics in the inner ear fluids: an animal study followed by clinical application. Laryngoscope 1999;109:1-17.

22. Herr BD, Marzo SJ. Intratympanic steroid perfusion for refractory sudden sensorineural hearing loss. Otolaryngol Head Neck Surg 2005;132:527-31.

This is an open access article distributed under the terms of the Creative Commons Attribution-NonCommercial-NoDerivs 3.0 Unported (CC BYNC-ND3.0) Licence (http://creativecommons.org/licenses/by-nc-nd/3.0/) which permits unrestricted noncommercial use, distribution, and reproduction in any medium, provided the original work is properly cited.

Please cite this article as: Gümüşsoy M, Arslan İB, Çukurova İ. Comparative efficacies of intratympanic steroid administration and classic therapy in the management of idiopathic sudden sensorineural hearing loss. J Med Updates 2013;3(2):51-55. 